\title{
Evaluasi Penggunaan Sistem Informasi ERP Dengan Metode Pieces Framework
}

\author{
Nani Agustina \\ AMIK BSI Jakarta \\ e-mail: nani.nna@bsi.ac.id
}

\begin{abstract}
Abstrak
Penggunaan sistem informasi pada saat ini sudah banyak digunakan oleh perusahaanperusahaan, misalnya PT. HK Realtindo Jakarta. Penerapan sistem informasi digunakan oleh beberapa bagian salah satunya bagian akuntansi keuangan dan bagian sales marketing. Penelitian menggunakan metode Pieces Framework dengan mengukur enam variabel diantaranya performance, information/data, economic, control, efficiency, dan service. Metode ini digunakan untuk mengukur tingkat penerimaan aplikasi sistem informasi yang sudah diterapkan terhadap pengguna. Pengguanan sistem informasi ini sudah lama digunakan sehingga diperlukan adanya penelitian terhadap sistem tersebut, pada penelitian ini terdapat 30 kuestioner yang diolah dan terdiri 20 indikator pertanyaan. Dalam penelitian ini menghasilkan data semua variabel baik dengan total penilaian performance sebesar 3,81, Information data sebesar 4,11, Economic menghasilkan nilai 4,07, securty/control mendapatkan point nilai 4,13, Efficiency dengan data nilai 4,13, dan service mendapatkan nilai 4,06. Dari hasil penelitian ini sistem informasi ERP sudah berjalan dengan baik tetapi pihak perusahaan tetap perlu melakakukan perbaikan-perbaikan untuk memberikan kepuasan dalam penggunaan sistem inforamasi tersebut.
\end{abstract}

Kata Kunci : Evaluasi kinerja, Sistem Informasi ERP, Metode Pieces Framework

\begin{abstract}
The use of information systems at this time has been widely used by companies, one of them is PT, HK Realtindo Jakarta. Implementation of information systems used by some parts of one part of financial accounting and sales marketing. Research using Pieces Framework method by measuring six variables such as performance, Information / data, Economic, Control, Efficiency, and service. This method is used to measure the level of acceptance of information system applications that have been applied to the user. The use of this information system has long been used so that the necessary research on the system, in this study there are 30 questionnaires are processed and consists of 20 indicators of questions. In this research yield data of all good variable with total performance appraisal 3,81, Information / data equal to 4,11, Economic mengahsilkan value 4,07, securty/control get point value 4,13, Efficiency with data value 4,13, and service get value 4.06 From the results of this research ERP information system is running well but the company still need melakakukan improvements to provide satisfaction in the use of the system informationt
\end{abstract}

\section{Keywords: Performance Evaluation, ERP Information System, Method Pieces Framework}

\section{Pendahuluan}

Penggunaan sistem informasi

sudah diterapkan diperusahaan sebagai media yang saling menghubungkan antara satu bagian dengan bagian lain untuk saling bertukar informasi baik berupa informasi yang sifatnya transaksi atau laporan. Pada intinya sistem informasi itu tidak lepas dari input-process-output, data yang diproses oleh sistem sehingga menghasilkan suatu output berupa informasi.

Sistem inforamsi berbasis web mengenai aplikasi pengolahan nilai dapat membantu dalam proses perhitungan nilai raport bagi yang berkepentingan dan memberikan kemudahan dalam bagi yang membutuhkan. (Susanti, Junianto, \& Rachman, 2017)

Masalah yang biasa dihadapi pihak hotel dan calon tamu seperti sulit dapat 
informasi yang cepat, sulitnya dalam proses check in dan check out. Solusi yang diberikan untuk menangani masalah tersebut dengan dibuatkan sebuah sistem informasi reservasi hotel berbasis web. (Mubarok \& Apriyanta, 2017)

Penggunaan sistem informasi yang paling popular saat ini adalah sistem informasi berbentuk ERP (Enterprise Resource Planning).

Perkembangan

bisnis menghendaki perpaduan dari berbagai unsur dengan tujuan untuk efisiensi, efektifitas, dan memberikan pelayanan yang prima serta harga yang dapat bersaing dengan maksud memberikan rasa kenyamanan dan kemudahan dari segala aspek-aspek lainnya dalam rangka memberikan rasa nyaman kepada pengguna. (Suryalena, 2013)

Penggunaan ERP ini memiliki kelebihannya dapat mengintegrasi antara area fungsional yang berbeda untuk meyakinkan komunikasi produktifitas dan efisiensi yang tepat. Sistem informasi telah digunakan sebagai alat untuk mendapatkan keunggulan dalam persaingan antar bisnis/ perusahaan.

Sebuah organisasi yang memiliki sistem informasi yang terancang baik secara umum akan memiliki keunggulan. Akan tetapi, kenyataan yang ada menunjukan bahwa implementasi suatu sistem informasi tidaklah mudah. Semakin banyak departemen terkait dengan sistem informasi maka semakin kompleks permasalahan dan resiko kegagalan juga semakin tinggi. Ketidakefektifan implementasi dari suatu sistem informasi yang saling terintegrasi sangat menggangu kinerja perusahaan dan perusahaan akan merugi. Sistem dianggap efektif jika user puas dalam menggunakan sistem tersebut dan kinerjanya meningkat. (Anneke, 2014)

Penelitian ini dilakukan pada Perusahaan properti PT. HK Realtindo Jakarta yang saat ini sudah mengimplementasikan sebuah sistem terintergrasi atau lebih dikenal dengan ERP (Enterprise Resource Planning). Mengukur dan melakukan evaluasi terhadap sistem informasi yang sudah diterapkan apakah dapat berjalan secara maksimal sesuai dengan keinginan dari perusahaan dengan menggunakan metode pieces framework.

\section{Sistem Informasi ERP (Enterprise Resource Planning)}

Perencanaan sumber daya perusahaan (Enteprise Resouce Planning/ ERP) adalah aplikasi komputer yang menyatukan sistem informasi yang mencakup berbagai fungsi utama perusahaan, seperti fungsi keuangan, produksi, pemasaran, sumberdaya manusia dan lain sebagainya. (Suryalena, 2013).

Dampak dari penerapan ERP seharusnya memberikan dampak positif bagi kinerja pengguna dalam hal ini pekerja dalam perusahaan. Faktor-faktor yang menjadi ukuran untuk menilai kinerja pengguna ERP dalam hal ini antara lain kualitas kerja (quality of work), kuantitas kerja (quantity of work), pengetahuan kerja (job knowledge), kreatifitas (creativeness), ketergantungan (dependability), inisiatif (initiative) dan kualitas personal (personal qualities). (Wicaksono, Mulyo, \& Riantono, 2015).

Modul-modul yang ada pada sistem ERP yang dibahas dalam penelitian :

1. Financial Accounting

Menyediakan pengukuran berkelanjutan terhadap keuntungan perusahaan baik secara internal maupun secara eksternal, fungsi dari modul ini menyediakan berkas-berkas yang berkaitan dengan keuangan (audit) setiap angka yang terdapat dalam setiap laporan.

2. Sales Distribution

Penggunaan strategi penjualan yang sangat sensitif terhadap adanya perubahan uang terjadi di pasar. Hal yang paling utama dari penggunaan modul membuat struktur data yang merekam, menganalisis, dan mengontrol aktivitas untuk memberikan rasa puas pelanggan dan menghasilkan profit untuk yang akan datang.

Penelitian adalah penyaluran rasa ingin tahu manusia terhadap masalah tersebut seperti memeriksa, mengusut, menelaah dan mempelajari secara cermat serta memformulasikan hipotesis sehingga diperoleh seseuatu seperti mencapai kebenaran, memperoleh jawaban atas masalah, pengembangan ilmu pengetahuan, dan sebagainya. (Siregar, 2013) Masalah yang biasa dihadapi pihak hotel dan calon tamu seperti sulit dapat informasi yang cepat, sulitnya dalam proses check in dan checkout. Solusi yang diberikan untuk menangani masalah 
tersebut dengan dibuatkan sebuah sistem informasi reservasi hotel berbasis web. (Mubarok \& Apriyanta, 2017)

Penelitian kuantitatif biasanya mengukur fakta objek melalui konsep yang diturunkan pada variabel-variabel dan dijabarkan pada indikator-indikator dengan memperhatikan aspek reliabilitas. (Abdurrahman, 2011)

Penelitian menggunakan teknik observasi dengan melihat bagaimana sistem ERP digunakan oleh bagian keuangan serta sales dan marketing, melakukan wawancara juga dilakukan untuk mengetahui secara lebih detail lagi tentang masalah dan kendala yang sering terjadi, selain itu melakukan penyebaran kuestioner untuk mendukung hasil dari penelitian. Langkah selajutnya melakukan study pustakaengan mencari referensi dan literatur-literatur yang berkaitan dengan sistem yang dibahas.

\section{Evaluasi Kinerja Sistem Informasi}

Evaluasi sistem informasi dapat dilakukan dengan cara berbeda dan pada tingkatan berbeda, tergantung pada tujuan evaluasinya. Evaluasi bermanfaat untuk mengetahui bagaimana implrmentasi suatu sistem telah dijalankan. Ada banyak evaluasi yang dapat dilakukan terhadap informasi, yaitu evalusai pra-implementasi, evaluasi review implementasi, evalusi operasional. (Apriyanti, Siti, \& Rahardjo, 2014)

Evaluasi dilakukan untuk mendefinisikan seberapa baik sistem dapat berjalan: (1) Menilai kemampuan teknis dari seluruh sistem informasi (2). Menilai keberhasilan dan kegagalan pelaksanaan operasional sistem informasi (Tullah \& Hanafri, 2014).

\section{Metode Penelitian}

\section{Metode PIECES Framework}

\begin{tabular}{rrrr}
\multicolumn{2}{c}{ PIECES } & Framework adalah \\
kerangka yang dipakai untuk
\end{tabular} mengklasifikasikan suatu problem, opportunities, dan directives yang terdapat pada bagian scopedefinition analisa dan perancangan sistem (Tullah \& Hanafri, 2014).

\section{Kehandalan / Performance}

Kinerja adalah suatu kumpulan sistem dalam menyelesaikan tugas dengan cepat sehingga sasaran dapat segera tercapai. Indkator yang mempengaruhi: a. Throughput, dimana sistem ini dinilai dari banyaknya kerja yang dilakukan pada beberapa periode waktu.

b. Respon time, yaitu delay rata-rata antara transaksi dan respon dari transaksi tersebut.

c. Audibilitas, yaitu kecocokan dimana keselarasan terhadap standar dapat diperiksa.

d. Kelaziman komunikasi, yaitu tingkat dimana interface sandar, protokol, dan bandwith digunakan.

e. Kelengkapan, yaitu derajat dimana implementasi penuh dari fungsi yang diharapkan tercapai.

f. Konsistensi, yaitu penggunaan desain dan teknik dokumentasi yang seragam pada keseluruhan proyek pengembangan perangkat lunak.

g. Toleransi kesalahan, yaitu kerusakan yang terjadi pada saat program mengalami kesalahan.

\section{Informasi Dan Data}

Informasi adalah hal penting karena dengan informasi terebut pihak manajemen dan user dapat melakukan langkah selanjutnya. Apabila kemampuan sistem informasi baik, maka user akan mendapatkan informasi yang akurat, tepat waktu dan relevan sesuai dengan yang diharapkan.

a. Accurancy (akurat) dimana informasi yang dihasilkan memiliki ketepatan yang tinggi.

b. Relevansi informasi, dimana informasi yang dihasilkan sesuai dengan kebutuhan.

c. Penyajian informasi, dimana informasi yang disajikan dalam bentuk yang sesuai dan mudah diintepretasikan.

d. Fleksibilitas data, dimana informasi mudah disesuaikan dengan kebutuhan.

\section{Nilai Ekonomis dari sistem} (Economics)

Pemanfaatan biaya yang digunakan dari pemanfaatan informasi. Peningkatan terhadap kebutuhan informasi yang ekonomis dapat mempengaruhi pengendalian biaya dan peningkatan manfaat terhadap sistem informasi

a. Reusabilitas, tingkat dimana sebuah program atau bagian dari program tersebut dapat digunakan kembali didalam aplikasi yang lainnya.

b. Sumber daya, jumlah sumber daya yang digunakan dalam pengembangan 
sistem, meliputi sumber daya manusia serta sumber daya ekonomi.

\section{Pengamanan dan Pengendalian (Control and Security)}

Analisis ini digunakan untuk membandingkan sistem yang dianalisa berdasarkan pada segi integritas sistem, kemudahan akses, dan kemanan data :

a. Integritas, tingkat dimana akses ke perangkat lunak atau data oleh orang yang tidak berhak dapat dikontrol.

b. Keamanan, yaitu mempunyai mekanisme yang mengontrol dan melindungi program.

5. Tingkat Keefisienan (Efficiency)

Efisiensi berhubungan dengan bagaimana sumber tersebut dapat digunakan secara optimal. Operasi pada suatu perusahaan dikatakan efisien atau tidak biasanya didasarkan pada tugas dan tanggung jawab dalam melaksanakan kegiatan.

a. Usabilitas, usaha yang dibutuhkan untuk mempelajari, mengoperasikan, menyiapkan input, dan mengintepretasikan output suatu program.

b. Maintanabilitas, usaha yang diperlukan untuk mencari dan membetulkan kesalahan pada sebuah program.

6. Pelayanan (Service)

\section{Peningakatan}

pelayanan

memperlihatkan kategori yang beragam. Peningkatan pelayanan yang lebih baik bagi manajemen, user dan bagian lain merupakan simbol kualitas dari suatu sistem informasi

a. Akurasi yaitu ketelitian komputasi dan control.

b. Reliabiilitas, tingkat dimana sebuah program dapat dipercaya melakukan fungsi yang diminta.

c. Kesederhaan yaitu tingkat dimana sebuah program dapat dipahami tanpa kesukaran.

\section{Metode Pengumpulan Data}

Dalam penelitian ini, penulis melakukan beberapa tahap pengumpulan data, berikut teknik yang digunakan :

1. Observasi

Untuk lebih mendapatkan gambaran tentang penggunaan sistem informasi tersebut.

2. Wawancara

Wawancara dilakukan terhadap karyawan yang menggunakan sistem informasi.
3. Angket

Pengumpulan data dengan memberikan kuestioner kepada responden kepada pengguna dari sistem informasi tersebut.

\section{Populasi dan Sample}

Populasi berasal dari bahasa Inggris yaitu population yang berarti jumlah penduduk, populasi merupakan keseluruhan (universum) dari objek penelitian yang dapat berupa manusia, hewan, tumbuh-tumbuhan, udara, gejala, nilai, peristiwa, sikap hidup dan sebagainya (Siregar, 2013)

Sedangkan sample adalah suatu prosedur pengambilan data dimana hanya sebagian populasi saja yang diambil dan dipergunakan untuk menentukan sifat serta ciri yang dikehendaki dari suatu populasi (Siregar, 2013)

\section{Metode Analisis Data}

Dalam mendapatkan hasil evalusi yang diinginkan maka diperlukan metode pengukuran. Skala kuestioner untuk memberikan pertanyaan maupun pernyataan untuk repsonden dengan menggunakan skala linkert dengan memberikan skor dari jawaban repsonden.

Tabel 1. Skala Linkert

\begin{tabular}{|l|c|c|}
\hline Jawaban & Akronim & Skor \\
\hline Sangat Setuju & SS & 5 \\
\hline Setuju & S & 4 \\
\hline Ragu-ragu & RG & 3 \\
\hline Tidak Setuju & TS & 2 \\
\hline Sangat Tidak Setuju & STS & 1 \\
\hline
\end{tabular}

Sumber : (Sugiyono, 2012)

Untuk melakukan analisis data, metode yang digunakan dengan cara menentuan nilai rata-rata dari tiap kuestioner, namun sebelum menentukan nilai rata-rata harus diketahui dulu nilai dari interval kelasnya untuk menentukan karakteristik penilaian terhadap sistem informasi ERP ini .

Di bawah ini rumus untuk mentukan interval kelasnya :

1. Rumus menentukan interval kelas

$\mathrm{I}=$ interval tiap bagian

$$
i=\frac{\mathrm{r}}{k}
$$

$r=$ range (skala tertinggi - skala terendah)

$\mathrm{k}=\mathrm{jumlah}$ bagian 
2. Karakteristik penilaian

$$
i=\frac{\mathrm{r}}{k}
$$

Nilai interval kelas yang didapatkan adalah 0,8 sehingga berdasarkan kombinasi skala linkert dan interval kelas, akan menghasikan tabel berikut:

Tabel 1. Skala Interval

\begin{tabular}{|c|c|}
\hline Skor & Skala \\
\hline 5 & $4,24-5,04$ \\
\hline 4 & $3,43-4,23$ \\
\hline 3 & $2,62-3,42$ \\
\hline 2 & $1,81-2,61$ \\
\hline 1 & $1,00-1,80$ \\
\hline
\end{tabular}

\section{Hasil dan Pembahasan}

Berdasarkan hasil penyebaran kuestioner / angket kepada 30 (tiga puluh) orang karyawan dari 2 (dua) bagian yang berbeda. Maka, hasil kuestioner diperhitungkan menggunakan rumus interval bagian dan dihitung nilai rata-rata berdasarkan variabel dari PIECES Framewok berdasarkan karakteristik penilaian.

\section{Tampilan Sistem Informasi ERP}

Peneliti akan membahas Sistem Informasi ERP yang ada di PT. HK Realtindo Jakarta, diantaranya terdapat 2 (dua) modul besar yaitu modul sales marketing dan modul akutansi keuangan.

1. Modul Sales Marketing

a. Tampilan Login

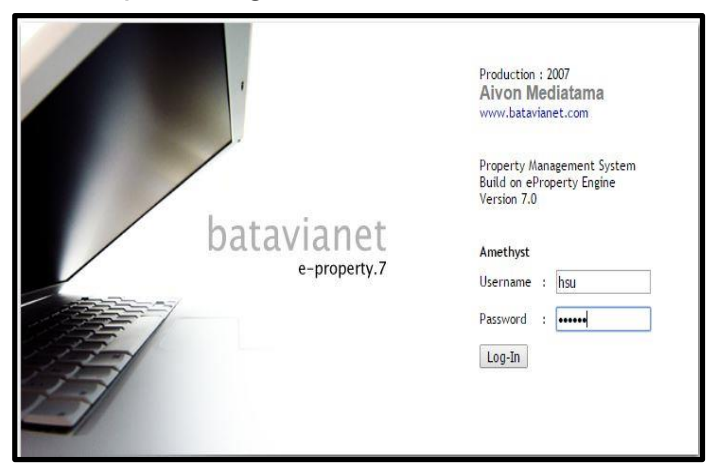

Gambar 1. Tampilan Login Sistem Informasi ERP Modul Sales Marketing

Sumber: PT. HK Realtindo Jakarta

Digunakan untuk pertama kali masuk ke dalam sistem difungsikan untuk mengatur akses dari para user untuk masuk ke modul sales dan marketing. b. Menu Utama

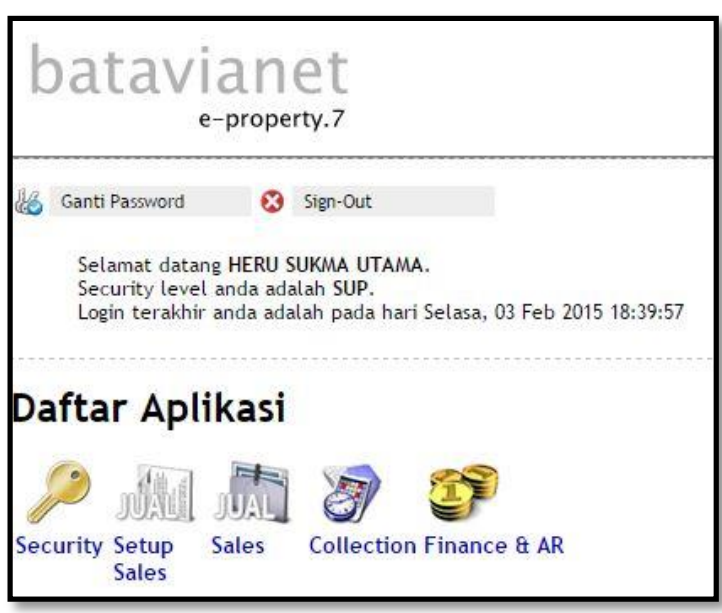

Gambar 2. Menu Utama Sistem Informasi ERP

Sumber : PT. HK Realtindo Jakarta

Digunakan untuk memilih menu yang akan digunakan terdapat 5 (lima) aplikasi di dalamnya (security, setup sales, collection, finance \& $A R$ ).

Digunakan untuk administrator sistem mengatur autorisasi terhadap username yang ada, dan digunakan untuk mengatur security level.

1) Login

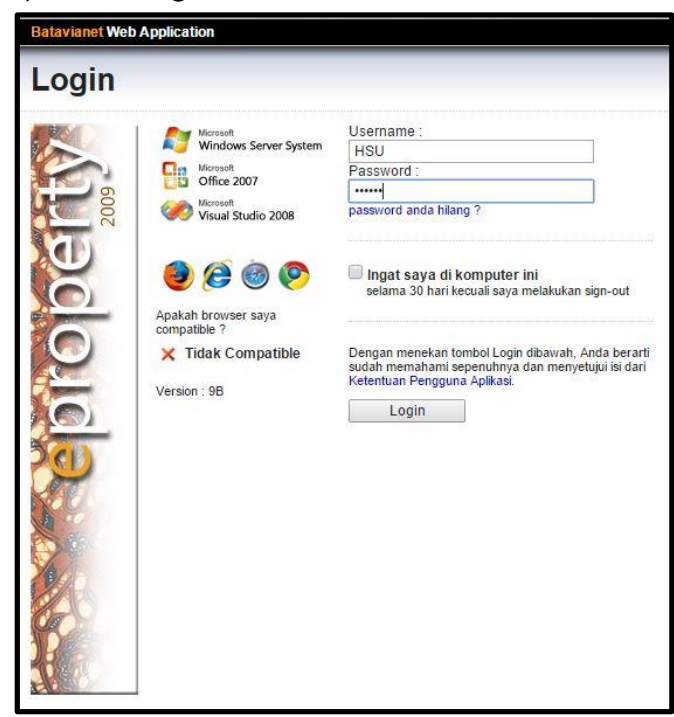

Gambar 3. Tampilan Menu Login Sistem Informasi ERP Modul Akutansi dan Keuangan

Sumber : PT. HK Realtindo Jakarta

Digunakan untuk pertama kali masuk ke dalam sistem difungsikan untuk mengatur akses dari para user untuk masuk ke modul akutansi dan keuangan. 


\section{2) Homepage}

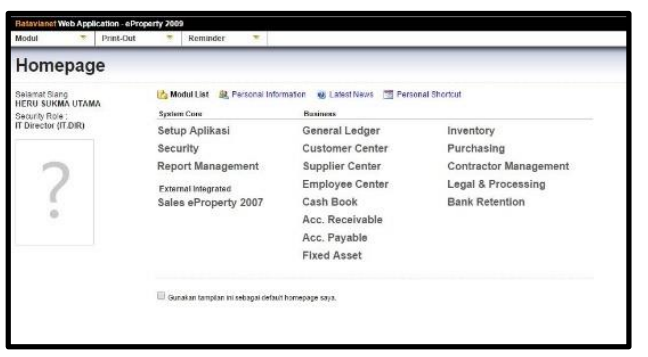

Gambar 4. Tampilan Menu Homepage Sistem Informasi ERP Modul Akutansi dan Keuangan

Sumber : PT. HK Realtindo Jakarta

Digunakan untuk memilih menu yang akan digunakan terdapat dua aplikasi didalamnya (system core dan business)

Berikut hasil perhitungan kuestioner terkait evaluasi penerapan sistem inforamasi ERP:

\subsection{Perhitungan perkriteria}

Dalam perhitungan ini terdapat 6 (enam) kriteria yang akan disajikan untuk pengisian kuestioner yang akan diolah sebanyak 30 (tiga puluh) kuestioner dan terdiri dari 6 (enam) kriteria yang akan diperhitungkan dimana terdapat 20 (dua puluh) jumlah pertanyaan.

\section{Kriteria Performance}

Pada kriteria ini terdapat 7 (tujuh) pertanyaan yang terkait dengan kriteria ini, hasil perhitungan disajikan dalam tabel.

Tabel 2. Hasil Kuestioener

\begin{tabular}{|c|c|c|c|c|c|c|c|}
\hline \multirow{2}{*}{ Kriteria } & \multicolumn{7}{|c|}{ Performance } \\
\hline Skor & 1 & 2 & 3 & 4 & 5 & 6 & 7 \\
\hline 1 & 1 & 2 & 0 & 0 & 0 & 0 & 0 \\
\hline 2 & 3 & 6 & 1 & 1 & 1 & 2 & 2 \\
\hline 3 & 10 & 11 & 6 & 6 & 6 & 0 & 6 \\
\hline 4 & 11 & 9 & 15 & 15 & 17 & 16 & 17 \\
\hline 5 & 5 & 2 & 8 & 8 & 6 & 12 & 5 \\
\hline Fre & 30 & 30 & 30 & 30 & 30 & 30 & 30 \\
\hline 1 & 1 & 2 & 0 & 0 & 0 & 0 & 0 \\
\hline 2 & 6 & 12 & 2 & 2 & 2 & 4 & 4 \\
\hline 3 & 30 & 33 & 18 & 18 & 18 & 0 & 18 \\
\hline 4 & 44 & 36 & 60 & 60 & 68 & 64 & 68 \\
\hline 5 & 25 & 10 & 40 & 40 & 30 & 60 & 25 \\
\hline Total & 106 & 93 & 120 & 120 & 118 & 128 & 115 \\
\hline Kriteria Information/ Data & & & \\
\hline
\end{tabular}

Kriteria Information/ Data

Pada kriteria ini terdapat 4 (empat) point pernyataan terkait dengan information atau data, hasil perhitungannya sebagai berikut :

Tabel 3. Hasil Kuestioner Information/Data

\begin{tabular}{|c|c|c|c|c|}
\hline Kriteria & \multicolumn{4}{|c|}{ Information/ Data } \\
\hline Skor & 1 & 2 & 3 & 4 \\
\hline 1 & 0 & 0 & 0 & 0 \\
\hline 2 & 1 & 5 & 1 & 2 \\
\hline 3 & 6 & 5 & 4 & 2 \\
\hline 4 & 13 & 8 & 14 & 11 \\
\hline 5 & 10 & 12 & 11 & 15 \\
\hline Fre & 30 & 30 & 30 & 30 \\
\hline 1 & 0 & 0 & 0 & 0 \\
\hline 2 & 2 & 10 & 2 & 4 \\
\hline 3 & 18 & 15 & 12 & 6 \\
\hline 4 & 52 & 32 & 56 & 44 \\
\hline 5 & 50 & 60 & 55 & 75 \\
\hline Total Skor & 122 & 117 & 125 & 129 \\
\hline
\end{tabular}

\section{Kriteria Economic}

Terdapat 2 (dua) point dalam kriteria ini yang terkait dengan pertanyaan seputar ekonomi dari sistem informasi ERP, hasil perhitungan dapat dilihat dalam tabel.

Tabel 4. Hasil Kuestioner Economic

\begin{tabular}{|c|c|c|}
\hline Kriteria & \multicolumn{2}{|c|}{ Economic } \\
\hline Skor & 1 & 2 \\
\hline 1 & 0 & 0 \\
\hline 2 & 0 & 1 \\
\hline 3 & 7 & 4 \\
\hline 4 & 17 & 14 \\
\hline 5 & 6 & 11 \\
\hline Fre & 30 & 30 \\
\hline 1 & 0 & 0 \\
\hline 2 & 0 & 2 \\
\hline 3 & 21 & 12 \\
\hline 4 & 68 & 56 \\
\hline 5 & 30 & 55 \\
\hline Total Skor & 119 & 125 \\
\hline
\end{tabular}

\section{Kriteria Control/ Securty}

Pada kriteria ini terdapat 2 (dua) point yang akan dijadikan pertanyaan, untuk mengetahui keamanan dari sistem informasi ERP, hasil perhitungan sebagai berikut: 
Tabel 5. Hasil Kuestioner Control/Securty

\begin{tabular}{|c|c|c|}
\hline Kriteria & \multicolumn{2}{|c|}{$\begin{array}{c}\text { Control/ } \\
\text { Securty }\end{array}$} \\
\hline Skor & 1 & 2 \\
\hline 1 & 0 & 0 \\
\hline 2 & 2 & 0 \\
\hline 3 & 2 & 7 \\
\hline 4 & 11 & 17 \\
\hline 5 & 15 & 6 \\
\hline Fre & 30 & 30 \\
\hline 1 & 0 & 0 \\
\hline 2 & 4 & 0 \\
\hline 3 & 6 & 21 \\
\hline 4 & 44 & 68 \\
\hline 5 & 75 & 30 \\
\hline Total Skor & 129 & 119 \\
\hline
\end{tabular}

\section{Kriteria Efficiency}

Terdapat 2 (dua) pertanyaan yang terkait dengan sistem ini yang berkaitan dengan efisiensi dari sistem, hasil perhitungan pada tabel.

Tabel 6. Hasil Kuestioner Efficiency

\begin{tabular}{|c|c|c|}
\hline Kriteria & \multicolumn{2}{|c|}{ Efficiency } \\
\hline Skor & 1 & 2 \\
\hline 1 & 0 & 0 \\
\hline 2 & 2 & 1 \\
\hline 3 & 4 & 6 \\
\hline 4 & 8 & 15 \\
\hline 5 & 16 & 8 \\
\hline Fre & 30 & 30 \\
\hline 1 & 0 & 0 \\
\hline 2 & 4 & 2 \\
\hline 3 & 12 & 18 \\
\hline 4 & 32 & 60 \\
\hline 5 & 80 & 40 \\
\hline Total Skor & 128 & 120 \\
\hline
\end{tabular}

\section{Kriteria Service}

Pada tahap service terdapat 3 (tiga) point yang berkaitan dengan layanan dari sistem informasi ERP, hasil perhitungan sebagai berikut:
Tabel 7. Hasil Kuestioner Service

\begin{tabular}{|c|c|c|c|}
\hline Kriteria & \multicolumn{3}{|c|}{ Service } \\
\hline Skor & 1 & 2 & 3 \\
\hline 1 & 0 & 0 & 0 \\
\hline 2 & 2 & 2 & 1 \\
\hline 3 & 0 & 6 & 6 \\
\hline 4 & 16 & 17 & 13 \\
\hline 5 & 12 & 5 & 10 \\
\hline Fre & 30 & 30 & 30 \\
\hline 1 & 0 & 0 & 0 \\
\hline 2 & 4 & 4 & 2 \\
\hline 3 & 0 & 18 & 18 \\
\hline 4 & 64 & 68 & 52 \\
\hline 5 & 60 & 25 & 50 \\
\hline Total Skor & 128 & 115 & 122 \\
\hline
\end{tabular}

\subsection{Mengitung Mean dan Total Variabel}

Berdasarkan hasil perhitungan di atas untuk menghitung total skor maka selanjutnya dilakukan perhitungan untuk mencari rata-rata setiap indikator pertanyaan.

(Mean)

Rumus menentukan nilai rata-rata

$$
\begin{aligned}
& r=\frac{\mathrm{ts}}{n} \\
& \mathrm{r}=\text { nilai rata-rata } \\
& \text { ts=total skor } \\
& \mathrm{n}=\text { jumlah responden }
\end{aligned}
$$

\begin{tabular}{|c|c|c|c|c|}
\hline Indikator & $\mathbf{F}$ & $\begin{array}{l}\text { Total } \\
\text { Skor }\end{array}$ & Mean & $\begin{array}{c}\text { Total } \\
\text { per } \\
\text { Var }\end{array}$ \\
\hline \multicolumn{5}{|c|}{ Performance } \\
\hline Throghput & 30 & 106 & 3,53 & \multirow{7}{*}{3,81} \\
\hline Respon time & 30 & 93 & 3,10 & \\
\hline Audabilitas & 30 & 120 & 4,00 & \\
\hline $\begin{array}{l}\text { Kelaziman } \\
\text { Komunikasi }\end{array}$ & 30 & 120 & 4,00 & \\
\hline Kelengkapan & 30 & 118 & 3,93 & \\
\hline Konsistensi & 30 & 128 & 4,27 & \\
\hline $\begin{array}{l}\text { Toleransi } \\
\text { Kesalahan }\end{array}$ & 30 & 115 & 3,83 & \\
\hline \multicolumn{5}{|c|}{ Information/ Data } \\
\hline Akurat & 30 & 122 & 4,07 & \multirow{4}{*}{4,11} \\
\hline $\begin{array}{l}\text { Relevansi } \\
\text { Informasi }\end{array}$ & 30 & 117 & 3,90 & \\
\hline $\begin{array}{l}\text { Penyajian } \\
\text { informasi }\end{array}$ & 30 & 125 & 4,17 & \\
\hline Fleksibilitas & 30 & 129 & 4,30 & \\
\hline
\end{tabular}

Total Var $=\frac{\text { Total Mean }}{\text { Jumlah Kriteria }}$

Tabel 8. Tabel MEAN dan Total Variabel 


\begin{tabular}{|c|c|c|c|c|}
\hline Indikator & $\mathbf{F}$ & $\begin{array}{l}\text { Total } \\
\text { Skor }\end{array}$ & Mean & $\begin{array}{c}\text { Total } \\
\text { per } \\
\text { Var }\end{array}$ \\
\hline Data & & & & \\
\hline \multicolumn{5}{|c|}{ Economic } \\
\hline Reusabilitas & 30 & 119 & 3,97 & \multirow{2}{*}{4,07} \\
\hline Sumber daya & 30 & 125 & 4,17 & \\
\hline \multicolumn{5}{|c|}{ Control/Securty } \\
\hline Integritas & 30 & 129 & 4,30 & \multirow{2}{*}{4,13} \\
\hline Keamanan & 30 & 119 & 3,97 & \\
\hline \multicolumn{5}{|c|}{ Efficiency } \\
\hline Usabilitas & 30 & 128 & 4,27 & \multirow{2}{*}{4,13} \\
\hline Maintanabilitas & 30 & 120 & 4,00 & \\
\hline \multicolumn{5}{|c|}{ Service } \\
\hline Akurasi & 30 & 128 & 4,27 & \multirow{3}{*}{4,06} \\
\hline Reliabilitas & 30 & 115 & 3,83 & \\
\hline Kesederhanaan & 30 & 122 & 4,07 & \\
\hline
\end{tabular}

Berdasarkan hasil perhitungan nilai rata-rata pada setiap kriteria didapatkan hasil total mean Performance sebesar 22,39 kemudian dibagi jumlah pertanyaan untuk kriteria Performance didapat hasil penilaian 3,81 dan berada pada kategori BAIK. Untuk kriteria Information/Data terdapat 4 (empat) indikator pertanyaan dengan total mean sebesar 16,44 dengan kategori BAIK dengan penilaian 4,11. Kriteria Economic terdapat 2 (dua) kriteria pertanyaan dengan hasil mean sebesar 8,14 dengan kategori BAIK didapat hasil penilaian 4,07. Pada kriteria Control/ Securty didapat total mean sebesar 8,27 dengan 2 (dua) pertanyaan yang berkaitan dengan kritera tersebut kemudian didapat hasil penilaian 4,13 dengan kategori BAIK, sedangkan untuk Efficiency mendapatkan total mean 8,27 dengan hasil penilaian 4,13 dengan katergori BAIK, dan yang terakhir adalan kriteria Service dengan kategori BAIK dengan total penilaian 4,06 dengan hasil total mean 12,17 dengan terdapat 3 (tiga) kriteria pertanyaan.

Dari hasil di atas terhadap pertanyaan yang diberikan kepada responden yang merupakan pengguna dari sistem informasi ERP pada variabel Performance, Information/Data, Economic, Control/Securty, Efficiency serta Service semuanya berada pada posisi BAIK dengan hasil ini artinya penerapan sistem informasi ERP dilingkungan perusahaan khususnya yang digunakan oleh bagian

Akuntansi dan keuangan serta marketing sales berdasarkan kerangka PIECES sudah dapat diterima oleh 2 (dua) bagian tersebut sebagai pengguna dari sistem informasi ERP.

\section{Kesimpulan}

Dengan meneliti tingkat penerimaan karyawan terhadap aplikasi ini didapatkan hasil secara keseluruhan dengan nilai sebesar 24,31 kemudian dibagi jumlah kriteria penelitian didapat hasil 4,05 dengan kategori BAIK. Dalam mengevaluasi sistem informasi ERP dengan menggunakan metode analisis PIECES framework dengan domain Performance, Information and data, Ecomoics, Control and security, Efficiency dan service sangat membantu dalam mengetahui kelemahan dan keunggulan sistem sehingga dapat menjadi evaluasi apakah sistem yang diterapkan layak atau tidak digunakan. Pada pengolahan data dan analisis semua variabel dalam kategori baik, sehingga perlu adanya peningkatan dan perbaikan sistem agar menjadi lebih baik ke depannya mendapatkan nilai Cukup Baik. Untuk lebih meningkatkan dari pengunaan aplikasi diperlukan pelatihan dan sosialisasi kepada pengguna dan perlunya adanya proses analisa kembali terhadap sistem dengan kerangka kerja yang lainnya, sehingga dapat menyakinkan bahwa penerapan sistem akan dapat berjalan lebih maksimal dan lebiih baik lagi.

\section{Referensi}

Abdurrahman, M. M. (2011). Panduan Praktis Memahami Penelitian. Bandung: Cv.Pustaka Setia.

Anneke, W. (2014). Efektivitas Implementasi Sistem Informasi Akuntansi Terintegrasi Pada Pt. Ace Hardware Indonesia Tbk., 2(2), 15791592. Retrieved From Https://Media.Neliti.Com/Media/Public ations/2148-Id-EfektivitasImplementasi-Sistem-InformasiAkuntansi-Terintegrasi-Pada-Pt-AceHar.Pdf

Apriyanti, E., Siti, N., \& Rahardjo, S. (2014). Evaluasi Sistem Informasi Manajemen Kepegawaian Berdasarkan Metode Pieces Di Puskesmas Wilayah Kerja Dinas Kesehatan Kabupaten Cilacap Tahun 2014. Jurnal Kesmasindo, 7, 
179-190. Retrieved From

Http://Jos.Unsoed.Ac.Id/Index.Php/Ke smasindo/Article/Download/130/119/

Mubarok, A., \& Apriyanta, M. R. (2017). Penerapan Aplikasi Web Di Hotel Arinda Guest House Bandung. Jurnal Informatika, 4(2), 272-276.

Siregar, S. (2013). Metode Penelitian Kuantitatif. Jakarta: Kencana Prenada Media Group.

Sugiyono. (2012). Metode Penelitian Kuantitatif Dan $R \& D$. Bandung: $C v$. Alfabeta.

Suryalena. (2013). Enterprise Resource Planning (Erp) Sebagai Tulang Punggung Bisnis Masa Kini. Jurnal Aplikasi Bisnis, 3, 145-154.

Susanti, S., Junianto, E., \& Rachman, R. (2017). Implementasi Framework Laravel Pada Aplikasi Pengolah Nilai Akademik Berbasis Web. Jurnal Informatika, 4(1), 108-117. Retrieved From

Http://Ejournal.Bsi.Ac.Id/Ejurnal//ndex. $\mathrm{Php} / \mathrm{Ji} /$ Article/View/1562/Pdf

Tullah, R., \& Hanafri, M. I. (2014). Evaluasi Penerapan Sistem Informasi Pada Politeknik Lp3i Jakarta Dengan Metode Pieces. Jurnal Sisfotek Global, 4(1), 22-28.

Wicaksono, A., Mulyo, H. H., \& Riantono, I. E. (2015). Analisis Dampak Penerapan Sistem Erp Terhadap Kinerja Pengguna. Binus Business Review, 6(9), 25-34. 